\title{
Relative efficacy of casein or soya protein combined with palm or safflower-seed oil on hyperuricaemia in rats
}

\author{
Hui-Chen Lo ${ }^{1}$, Yao-Horng Wang ${ }^{2}$, Hue-Ying Chiou ${ }^{3}$, Shan-Hu Lai ${ }^{4}$ and Yu Yang ${ }^{5 *}$ \\ ${ }^{1}$ Department of Nutritional Science, Fu Jen Catholic University, no. 510 Jhongjheng Road, Sinjhuang City, Taipei County 24205, \\ Taiwan \\ ${ }^{2}$ Department of Nursing, College of Health Sciences, Yuanpei University, no. 306, Yuan-Pei Street, Hsin-Chu City 30015, Taiwan \\ ${ }^{3}$ Division of Animal Medicine, Animal Technology Institute Taiwan, no. 52 Kedung 2 Road, Ding-Pu Lii, Chunan, Miaoli 35053, \\ Taiwan \\ ${ }^{4}$ Centre for General Education, Jen-Teh Junior College of Medicine, no. 79-9 Sijhou Neighborhood Shalunhu, Houlong Township, \\ Miaoli County 356, Taiwan \\ ${ }^{5}$ Division of Nephrology, Internal Medicine, Changhua Christian Hospital, no. 135 Nanhsiao Street, Changhua 50006, Taiwan \\ (Received 20 July 2009 - Revised 15 December 2009 - Accepted 16 December 2009 - First published online 1 March 2010)
}

\begin{abstract}
Diets that ameliorate the adverse effects of uric acid (UA) on renal damage deserve attention. The effects of casein or soya protein combined with palm or safflower-seed oil on various serum parameters and renal histology were investigated on hyperuricaemic rats. Male Wistar rats administered with oxonic acid and UA to induce hyperuricaemia were fed with casein or soya protein plus palm- or safflower-seed oil-supplemented diets. Normal rats and hyperuricaemic rats with or without allopurinol treatment $(150 \mathrm{mg} / \mathrm{l}$ in drinking water) were fed with casein plus maize oilsupplemented diets. After 8 weeks, allopurinol treatment and soya protein plus safflower-seed oil-supplemented diet significantly decreased serum UA in hyperuricaemic rats (one-way ANOVA; $P<0.05$ ). In addition, soya protein and casein attenuated hyperuricaemia-induced decreases in serum albumin and insulin, respectively (two-way ANOVA; $P<0 \cdot 05$ ). Safflower-seed oil significantly decreased serum TAG and UA, whereas palm oil significantly increased serum cholesterol, TAG, blood urea $\mathrm{N}$ and creatinine. However, soya protein significantly decreased renal NO and nitrotyrosine and palm oil significantly decreased renal nitrotyrosine, TNF- $\alpha$ and interferon- $\gamma$ and increased renal transforming growth factor- $\beta$. Casein with safflower-seed oil significantly attenuated renal tubulointerstitial nephritis, crystals and fibrosis. Comparing casein $v$. soya protein combined with palm or safflower-seed oil, the results support that casein with safflower-seed oil may be effective in attenuating hyperuricaemia-associated renal damage, while soya protein with safflower-seed oil may be beneficial in lowering serum UA and TAG.
\end{abstract}

Uric acid: TAG: Cytokines: NO: Renal histology

The prevalence of hyperuricaemia is high in Taiwan, especially in the elderly and aborigines, which cannot be completely explained by obesity and alcohol consumption ${ }^{(1-3)}$. Genetic components and environmental factors may play certain roles in this variation of occurrence ${ }^{(1)}$. Typically, hyperuricaemia, i.e. a serum uric acid (UA) level greater than $70 \mathrm{mg} / \mathrm{l}$, is regarded as a marker of gout ${ }^{(4)}$. CVD, hypertension and metabolic disorders are also closely associated with hyperuricaemia ${ }^{(2,3,5-7)}$. The question of whether hyperuricaemia can induce chronic renal injury has been argued for many years. Recently, UA has been proven to be a mediator of renal disease progression ${ }^{(5,6,8-10)}$.

In most mammals, UA, a purine metabolite, is degraded by the hepatic enzyme uricase to allontoin. However, mutations in the uricase gene have occurred during human development with the consequence that man has relatively higher levels of serum $\mathrm{UA}^{(6)}$. Several studies have demonstrated that hyperuricaemia is associated with glomerular hypertension ${ }^{(8)}$, lumen obliteration $^{(11)}$, tubulointerstitial inflammation and fibrosis ${ }^{(12)}$ and end-stage renal disease ${ }^{(13)}$. Using rats administered with UA and oxonic acid (OA), an inhibitor of uricase capable of reproducing the enzyme deficiency in the human species, Johnson et al. ${ }^{(6)}$ developed an animal model with marked hyperuricaemia and renal crystal deposition. Subsequently, they used OA alone to develop a mild hyperuricaemic rat model and showed that allopurinol treatment, the only US Food and Drug Administration-approved xanthine oxidase inhibitor for the treatment of hyperuricaemia, may prevent

Abbreviations: BUN, blood urea N; HY-AL, hyperuricaemic rats fed with casein and maize oil; HY + AL, hyperuricaemic rats fed with casein and maize oil and administered with allopurinol in drinking water; HY $+\mathrm{CP}$, hyperuricaemic rats fed with casein and palm oil; HY + CS, hyperuricaemic rats fed with casein and safflower-seed oil; HY + SP, hyperuricaemic rats fed with soya protein and palm oil; HY + SS, hyperuricaemic rats fed with soya protein and safflower-seed oil; IFN, interferon; OA, oxonic acid; PAS, periodic acid-Schiff; R, normal control rats fed with a modified AIN-93M high-fat diet; TGF, transforming growth factor; UA, uric acid; UFA, unsaturated fatty acid.

* Corresponding author: Dr Yu Yang, fax +886 4722 8289, email 2219@cch.org.tw 
blood pressure elevation and tubulointerstitial injury ${ }^{(5,6)}$. To mimic clinical situations of hyperuricaemic patients who have developed renal damage, both OA and UA were used to induce hyperuricaemia in rats in the present study.

It has been indicated that eliminating the source and elevating the excretion of UA are useful approaches to attenuate hyperuricaemia $^{(14)}$. Therefore, a dietary approach might be helpful in preventing hyperuricaemia-associated renal dysfunction and failure. The conventional management of hyperuricaemia includes an energy-adapted diet with moderate amounts of fat, restriction of alcohol, an ovolactovegetarian diet low in purine and adequate amounts of energy-free liquid $^{(15,16)}$. Recently, a weight-reducing, purine-unlimited, energy- and carbohydrate-restricted diet with an increased proportional intake of protein and unsaturated fatty acids (UFA) has been proposed ${ }^{(17)}$. For example, in rats with chronic kidney disease, a soya-based diet significantly reduced serum UA, renal fibrosis and renal cyst growth compared with a casein-based diet ${ }^{(18)}$. In addition, the favourable effects of various plant oils on glomerular protection have been seen in spontaneously hypertensive rats $^{(19)}$.

From current studies, it is difficult to conclude whether or not there is a long-term association between the consumption of casein, soya protein and various plant oils with the changes in renal function ${ }^{(20)}$. Based on the above studies, we hypothesised that a soya protein-based diet supplemented with UFA may be beneficial to lower serum UA and to attenuate the adverse effects of hyperuricaemia. Therefore, the present study is designed to compare the effects of casein $v$. soya protein with two commonly used plant oils with different fatty acid components, i.e. palm (palmitic and oleic acidrich) and safflower-seed (linoleic acid-rich) oils, on various serological parameters and renal damage induced by hyperuricaemia.

\section{Materials}

\section{Animals and experimental design}

Male Wistar rats, initially weighing 180-200 g and aged 5-6 weeks, were acclimatised to the animal facility with free access to water and a chow diet in a room maintained at $22^{\circ} \mathrm{C}$ on a $12 \mathrm{~h}$ light $-12 \mathrm{~h}$ dark cycle for several days before the experiment. After fasting overnight, the animals were divided into seven groups (nine rats per group) and fed with modified American Institute of Nutrition (AIN)-93M high-fat diets with approximately $30 \%$ of the total energy from fat (Table 1). Six groups of animals were fed with diets containing $2 \% \mathrm{OA}(\mathrm{w} / \mathrm{w})$ and $3 \% \mathrm{UA}(\mathrm{w} / \mathrm{w})$ for the induction of marked hyperuricaemia with renal injury and intratubular crystal deposition based on the pilot studies of Mazzali et $a l .{ }^{(5)}$. The study design was as follows:

R group: normal control rats fed with a modified AIN-93M high-fat diet, which contained casein and maize oil (ICN Biomedicals, Inc., Cleveland, OH, USA) as the protein and fat sources, respectively.

HY-AL group: hyperuricaemic rats fed with casein and maize oil.

Table 1. Nutrition composition of experimental diets*

\begin{tabular}{|c|c|c|c|c|c|c|}
\hline Diet... & $\mathrm{R}$ & $\mathrm{HY}-\mathrm{AL}$ and $\mathrm{HY}+\mathrm{AL}$ & $\mathrm{HY}+\mathrm{CP}$ & $\mathrm{HY}+\mathrm{CS}$ & $\mathrm{HY}+\mathrm{SP}$ & $\mathrm{HY}+\mathrm{SS}$ \\
\hline \multicolumn{7}{|c|}{ Major ingredients ( $\mathrm{g} / 100 \mathrm{~g}$ diet) } \\
\hline Casein & $14 \cdot 0$ & $14 \cdot 0$ & $14 \cdot 0$ & $14 \cdot 0$ & - & - \\
\hline Soya protein & - & - & - & - & $14 \cdot 0$ & $14 \cdot 0$ \\
\hline Maize starch & 46.5692 & 46.5692 & 46.5692 & 46.5692 & 46.5692 & 46.5692 \\
\hline Sucrose & 15.5 & $10 \cdot 5$ & 10.5 & $10 \cdot 5$ & 10.5 & $10 \cdot 5$ \\
\hline Cellulose & $5 \cdot 0$ & $5 \cdot 0$ & $5 \cdot 0$ & $5 \cdot 0$ & $5 \cdot 0$ & $5 \cdot 0$ \\
\hline AIN-93M mineral mix & 3.5 & 3.5 & 3.5 & 3.5 & 3.5 & 3.5 \\
\hline AIN-93 vitamin mix & $1 \cdot 0$ & $1 \cdot 0$ & $1 \cdot 0$ & 1.0 & 1.0 & 1.0 \\
\hline Choline bitartrate & 0.25 & 0.25 & 0.25 & 0.25 & 0.25 & 0.25 \\
\hline L-Cystine & 0.18 & $0 \cdot 18$ & 0.18 & $0 \cdot 18$ & $0 \cdot 18$ & $0 \cdot 18$ \\
\hline$t$-Butylhydroquinone & 0.0008 & 0.0008 & 0.0008 & 0.0008 & 0.0008 & 0.0008 \\
\hline Oxonic acid & - & $2 \cdot 0$ & $2 \cdot 0$ & $2 \cdot 0$ & $2 \cdot 0$ & $2 \cdot 0$ \\
\hline Uric acid & - & $3 \cdot 0$ & 3.0 & 3.0 & 3.0 & $3 \cdot 0$ \\
\hline Maize oil & $14 \cdot 0$ & $14 \cdot 0$ & - & - & - & - \\
\hline Safflower-seed oil & - & - & - & $14 \cdot 0$ & - & $14 \cdot 0$ \\
\hline Palm oil & - & - & $14 \cdot 0$ & - & $14 \cdot 0$ & - \\
\hline \multicolumn{7}{|c|}{ Fatty acid distribution (\% total fatty acids) } \\
\hline 14:0 (Myristic acid) & - & - & $0.5-6.0$ & 0.1 & $0.5-6.0$ & 0.1 \\
\hline $16: 0$ (Palmitic acid) & $11 \cdot 2$ & $11 \cdot 2$ & $35 \cdot 0-48.0$ & $6 \cdot 0-7.5$ & $35 \cdot 0-48 \cdot 0$ & $6.0-7.5$ \\
\hline 18:0 (Stearic acid) & $2 \cdot 1$ & $2 \cdot 1$ & $3 \cdot 0-7 \cdot 0$ & $2 \cdot 0-2 \cdot 5$ & $3 \cdot 0-7 \cdot 0$ & $2 \cdot 0-2 \cdot 5$ \\
\hline $18: 1$ (Oleic acid) & $25 \cdot 0$ & $25 \cdot 0$ & $35 \cdot 0-50 \cdot 0$ & $11 \cdot 0-13.5$ & $35 \cdot 0-50 \cdot 0$ & $11 \cdot 0-13.5$ \\
\hline 18:2 (Linoleic acid) & 59.9 & 59.9 & $6 \cdot 0-13 \cdot 0$ & $70 \cdot 0-80 \cdot 0$ & $6 \cdot 0-13 \cdot 0$ & $70 \cdot 0-80 \cdot 0$ \\
\hline $18: 3$ (Linolenic acid) & 0.5 & 0.5 & - & $\leq 3.3$ & - & $\leq 3.3$ \\
\hline Total SFA & 13.3 & $13 \cdot 3$ & $38.5-61.0$ & $9 \cdot 0$ & $38.5-61.0$ & $9 \cdot 0$ \\
\hline Total MUFA & $25 \cdot 0$ & $25 \cdot 0$ & $35 \cdot 0-50 \cdot 0$ & $13 \cdot 0$ & $35 \cdot 0-50 \cdot 0$ & $13 \cdot 0$ \\
\hline Total PUFA & 60.4 & $60 \cdot 4$ & $6 \cdot 0-13 \cdot 0$ & 78.0 & $6 \cdot 0-13 \cdot 0$ & $78 \cdot 0$ \\
\hline
\end{tabular}

R, normal control rats fed with a modified AIN-93M high-fat diet; HY-AL, hyperuricaemic rats fed with casein and maize oil; HY $+\mathrm{AL}$, hyperuricaemic rats fed with casein and maize oil and administered with allopurinol in drinking water; HY $+\mathrm{CP}$, hyperuricaemic rats fed with casein and palm oil; HY + CS, hyperuricaemic rats fed with casein and safflower-seed oil; HY + SP, hyperuricaemic rats fed with soya protein and palm oil; HY + SS, hyperuricaemic rats fed with soya protein and safflower-seed oil; AIN, American Institute of Nutrition.

*All of the ingredients were purchased from ICN Biomedical, Inc. (Cleveland, OH, USA), except for palm oil, which was purchased from Sigma-Aldrich Co. (St Louis, MO, USA). 
$\mathrm{HY}+\mathrm{AL}$ group: hyperuricaemic rats fed with casein and maize oil and administered with allopurinol $(150 \mathrm{mg} / \mathrm{l})$ in drinking water.

$\mathrm{HY}+\mathrm{CP}$ group: hyperuricaemic rats fed with casein and palm oil (Fluka 70905; Sigma-Aldrich Co., St Louis, MO, USA).

HY + CS group: hyperuricaemic rats fed with casein and safflower-seed oil (ICN Biomedicals, Inc.).

$\mathrm{HY}+\mathrm{SP}$ group: hyperuricaemic rats fed with soya protein (soya protein isolate, ICN no. 905456; ICN Biomedicals, Inc.) and palm oil.

HY + SS group: hyperuricaemic rats fed with soya protein and safflower-seed oil.

All of the diets provided identical amounts of protein $(14 \% \mathrm{w} / \mathrm{w})$, fat $(14 \%)$, maize starch $(46.6 \%)$, fibre $(5 \%)$, minerals and vitamins (ICN Biomedicals, Inc.), but not sucrose $(15.5$ or $10.5 \%)$. All of the rats were pair-fed with the HY-AL rats from week 1 to week 8 . The animals were individually housed in stainless-steel cages for 8 weeks during the experimental period.
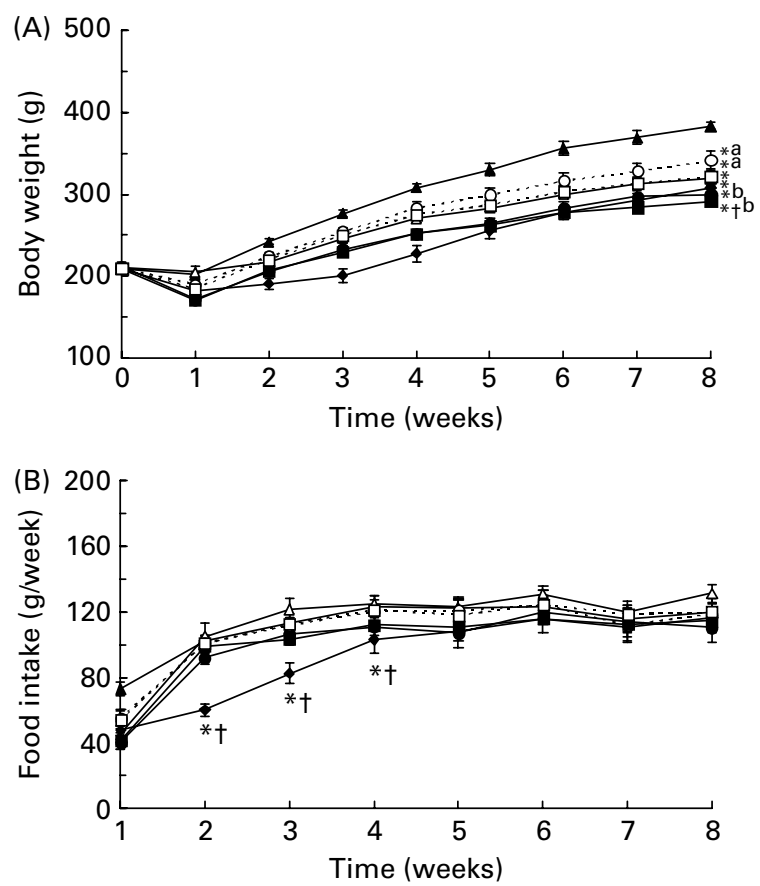

Fig. 1. Body weight $(A)$ and the amount of food intake (B) during 8 weeks. $(-\boldsymbol{\Delta}-)$, Normal control rats fed with a modified American Institute of Nutrition (AIN)-93M high-fat diet (R); $(-\triangle-)$, hyperuricaemic rats fed with casein and maize oil (HY-AL); $(--)$, hyperuricaemic rats fed with casein and maize oil

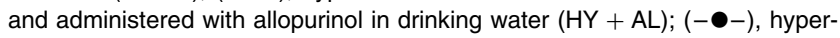
uricaemic rats fed with casein and palm oil (HY + CP); (- - - - ), hyperuricaemic rats fed with casein and safflower-seed oil (HY $+\mathrm{CS}) ;(-\mathbf{-}-)$, hyperuricaemic rats fed with soya protein and palm oil (HY + SP); (-- $\square--)$, hyperuricaemic rats fed with soya protein and safflower-seed oil (HY $+\mathrm{SS}$ ). Values are means for nine rats per group, with standard errors represented by vertical bars. ${ }^{*}$ Mean value was significantly different from that of the $R$ group ( $P<0.05$; one-way ANOVA and least significant differences). † Mean value was significantly different from that of the HY-AL group $(P<0.05$; oneway ANOVA and least significant differences). ${ }^{a, b}$ Mean values (among the $\mathrm{HY}+\mathrm{CP}, \mathrm{HY}+\mathrm{CS}, \mathrm{HY}+\mathrm{SP}$ and $\mathrm{HY}+\mathrm{SS}$ groups) with unlike letters were significantly different $(P<0.05)$.
Body weight was recorded twice per week and food intake was recorded every day. Approximately $0.5 \mathrm{ml}$ of fasting blood samples were collected from the tail vein for UA and TAG determinations before the treatment (week 0 ) and on weeks 2, 4, 6 and 8 (on the day before killing). On week 8 , animals were killed after being anaesthetised with ketamine $(150 \mathrm{mg} / \mathrm{kg})$ and xylazine $(15 \mathrm{mg} / \mathrm{kg})$. Blood samples were collected by cardiac puncture and separated into whole blood, serum and plasma for further analysis. The kidneys, liver, heart, lungs and gastrocnemius muscles of each rat were dissected and weighed. The left kidney was collected and fixed with $10 \%$ neutral buffered formalin and the right kidney was put into liquid $\mathrm{N}_{2}$ immediately and stored at $-80^{\circ} \mathrm{C}$

\section{Analytic measurements}

The numbers of circulating leucocytes were determined by a haematology analyser (GEN; Beckman Coulter Inc., Miami, FL, USA). Serum concentrations of albumin, blood urea N (BUN) and creatinine were measured by an automatic analyser (Hitachi 747; Hitachi, Tokyo, Japan). Commercially available kits were used to measure serum concentrations of glucose, TAG, cholesterol and UA (Diagnostic Chemicals Ltd, Oxford, CT, USA). A commercially available ELISA kit was used to measure plasma insulin (Mercoda AB, Uppsala, Sweden).

The right kidney was homogenised by polytrone in a 10-fold volume of PBS. The concentrations of NO (represented by nitrite and nitrate) in the serum and renal homogenates were measured by a colorimetric assay kit (lactate dehydrogenase method; Cayman Chemical, Ann Arbor, MI, USA). Concentrations of cytokines, such as TNF- $\alpha$ and interferon (IFN)- $\gamma$ in the plasma and renal homogenates, and that of transforming growth factor (TGF)- $\beta$ and nitrotyrosine in the renal homogenates were measured by commercially available ELISA kits (R\&D System, Minneapolis, MN, USA and OXIS International Inc., Foster City, CA, USA). Samples were analysed in one assay in duplicate.

At killing, the renal capsule of the left kidney was removed and then immersion fixed in $10 \%$ neutral buffered formalin and embedded in paraffin. Then $4 \mu \mathrm{m}$ sections of paraffinembedded kidney were stained with periodic acid-Schiff (PAS). PAS is mainly used for staining structures containing a high proportion of carbohydrate macromolecules, such as glycoproteins. Morphological analyses, including tubulointerstitial nephritis, intralesional calcification, urate crystal and fibrosis, were performed under a light microscope. The extent of injury was graded on a scale of 0 to 4 by an observer blinded to the animal treatment group according to the study of Shih et al. ${ }^{(21)}$. With this method, the extent of injury was graded as 0 for normal, 1 for trace damage, 2 for weak damage, 3 for moderate damage, and 4 for strong damage, which involved $0 \%, 1$ to $25 \%, 25$ to $50 \%, 50$ to $75 \%$, and 75 to $100 \%$ of the area in the renal sections, respectively.

\section{Statistical analysis}

Values were expressed as mean values with their standard errors. Comparisons of each parameter among all of the groups and hyperuricaemic groups were determined by 
Table 2. Relative organ weights in normal and hyperuricaemic rats

(Mean values with their standard errors for nine rats per group)

\begin{tabular}{|c|c|c|c|c|c|c|c|c|c|c|c|c|c|c|}
\hline \multirow[b]{2}{*}{ Group } & \multicolumn{2}{|c|}{$\begin{array}{l}\text { BW gain } \\
\text { (g/8 weeks) }\end{array}$} & \multicolumn{2}{|c|}{$\begin{array}{l}\text { Feed efficiency } \\
(\mathrm{mg} / \mathrm{kJ})\end{array}$} & \multicolumn{2}{|c|}{ Heart $(\mathrm{g} / \mathrm{kg})$} & \multicolumn{2}{|c|}{ Lung $(\mathrm{g} / \mathrm{kg})$} & \multicolumn{2}{|c|}{ Liver $(\mathrm{g} / \mathrm{kg})$} & \multicolumn{2}{|c|}{ Kidney (g/kg) } & \multicolumn{2}{|c|}{$\begin{array}{l}\text { Gastrocnemius } \\
\text { muscle }(\mathrm{g} / \mathrm{kg})\end{array}$} \\
\hline & Mean & SE & Mean & SE & Mean & SE & Mean & SE & Mean & SE & Mean & SE & Mean & SE \\
\hline $\mathrm{R}$ & $174 \cdot 2$ & $6 \cdot 7$ & $10 \cdot 84$ & 0.37 & 2.79 & 0.07 & 4.62 & $0 \cdot 10$ & 28.12 & 0.98 & $6 \cdot 20$ & 0.19 & 12.44 & 0.28 \\
\hline HY-AL & $114 \cdot 0^{*}$ & $9 \cdot 7$ & $7 \cdot 13^{*}$ & 0.48 & 2.97 & 0.08 & $5 \cdot 15^{*}$ & 0.15 & $27 \cdot 21$ & 1.07 & $7 \cdot 32^{\star}$ & 0.39 & 12.98 & 0.52 \\
\hline $\mathrm{HY}+\mathrm{AL}$ & $98 \cdot 3^{\star}$ & $6 \cdot 2$ & $8 \cdot 13^{*}$ & 0.29 & $3.04^{*}$ & 0.04 & $5.45^{\star}$ & 0.12 & 26.85 & 0.53 & $8 \cdot 13^{\star}$ & 0.29 & $13 \cdot 21$ & 0.30 \\
\hline $\mathrm{HY}+\mathrm{CP}$ & $90 \cdot 9^{*} t^{b}$ & $2 \cdot 7$ & $6 \cdot 48^{\mathrm{kb}, \mathrm{c}}$ & 0.27 & $3 \cdot 22^{*} t^{a}$ & 0.06 & $5 \cdot 72^{*}$ & 0.30 & 26.09 & 0.46 & $8.81^{*} \dagger$ & 0.49 & 12.98 & 0.25 \\
\hline $\mathrm{HY}+\mathrm{CS}$ & $130 \cdot 3^{\star a}$ & 8.9 & $8.48^{*} t^{a}$ & 0.52 & $2 \cdot 95^{\mathrm{b}}$ & 0.06 & $5 \cdot 02$ & 0.14 & $25 \cdot 89^{*}$ & 0.54 & $7 \cdot 98^{*}$ & 0.36 & 13.31 & 0.36 \\
\hline $\mathrm{HY}+\mathrm{SP}$ & $83 \cdot 2^{*} t^{b}$ & $6 \cdot 6$ & $5 \cdot 91^{*} \dagger^{\mathrm{C}}$ & 0.39 & $3 \cdot 21^{*} \dagger^{a}$ & 0.06 & $5 \cdot 48^{\star}$ & 0.11 & $24 \cdot 86^{*} \dagger$ & 0.71 & $8.82^{*} \dagger$ & 0.34 & $13 \cdot 78^{*}$ & 0.22 \\
\hline $\mathrm{HY}+\mathrm{SS}$ & $111 \cdot 7^{\star \mathrm{a}}$ & 8.6 & $7 \cdot 49^{* \mathrm{~b}}$ & 0.39 & $3.05^{\star a, b}$ & 0.10 & $5 \cdot 16^{\star}$ & 0.14 & $24 \cdot 19^{*} \dagger$ & 0.83 & $9 \cdot 15^{\star} \dagger$ & 0.33 & $14.77^{*} \dagger$ & 0.83 \\
\hline \multicolumn{15}{|c|}{ Main effects for four groups (two-way ANOVA) $\ddagger$} \\
\hline Protein & NS & & 0.034 & & NS & & NS & & 0.032 & & NS & & 0.045 & \\
\hline Oil & $<0.001$ & & $<0.001$ & & 0.004 & & 0.009 & & NS & & NS & & NS & \\
\hline Interaction & NS & & NS & & NS & & NS & & NS & & NS & & NS & \\
\hline
\end{tabular}

BW, body weight; R, normal control rats fed with a modified AIN-93M high-fat diet; HY-AL, hyperuricaemic rats fed with casein and maize oil; HY + AL, hyperuricaemic rats fed with casein and maize oil and administered with allopurinol in drinking water; HY + CP, hyperuricaemic rats fed with casein and palm oil; HY + CS, hyperuricaemic rats fed with casein and safflower-seed oil; HY + SP, hyperuricaemic rats fed with soya protein and palm oil; HY + SS, hyperuricaemic rats fed with soya protein and safflower-seed oil; AIN, American Institute of Nutrition.

a,b,c Mean values within a column (among the $\mathrm{HY}+\mathrm{CP}, \mathrm{HY}+\mathrm{CS}, \mathrm{HY}+\mathrm{SP}$ and $\mathrm{HY}+\mathrm{SS}$ groups) with unlike superscript letters were significantly different $(P<0.05)$

* Mean value was significantly different from that of the $\mathrm{R}$ group $(P<0.05$; one-way ANOVA and least significant differences).

† Mean value was significantly different from that of the HY-AL group $(P<0.05$; one-way ANOVA and least significant differences).

$\ddagger$ Values of two-way ANOVA are $P$ values for main effects, such as protein, oil and interaction between protein and oil in the HY $+\mathrm{CP}, \mathrm{HY}+\mathrm{CS}, \mathrm{HY}+\mathrm{SP}$ and $\mathrm{HY}+\mathrm{SS}$ groups.

one-way ANOVA using the SAS general linear models program. A repeated-measures analysis was used to determine the main effects of group and time on body weight, serum TAG and serum UA during the experimental period. In addition, two-way ANOVA analysis was used to determine the effects of protein and fat sources for each parameter among the $\mathrm{HY}+\mathrm{CP}, \mathrm{HY}+\mathrm{CS}, \mathrm{HY}+\mathrm{SP}$ and $\mathrm{HY}+\mathrm{SS}$ groups. Group means were considered to be significantly different at $P<0.05$, as determined by the protective least-significant difference technique when the ANOVA indicated an overall significant group effect $(P<0 \cdot 05)$. The KruskalWallis test was used for morphological analyses of renal sections, followed by least-significant difference tests to determine whether intergroup differences were significant.

The animal facilities and protocols were reviewed and approved by the Institutional Animal Care and Use Committee (IACUC) in Changhua Christian Hospital, Changhua, Taiwan, with approval no. CCH-AE-95 005. Rats were maintained in accordance with the Guidelines for the Care and Use of Laboratory Animals of Changhua Christian Hospital.

Table 3. Leucocytes and serum biochemistry in normal and hyperuricaemic rats (Mean values with their standard errors for nine rats per group)

\begin{tabular}{|c|c|c|c|c|c|c|c|c|c|c|}
\hline \multirow[b]{2}{*}{ Group } & \multicolumn{2}{|c|}{$\begin{array}{l}\text { Leucocytes } \\
\left(10^{3} / \mu \mathrm{l}\right)\end{array}$} & \multicolumn{2}{|c|}{ Albumin (g/l) } & \multicolumn{2}{|c|}{ Cholesterol (mg/l) } & \multicolumn{2}{|c|}{ BUN (mg/l) } & \multicolumn{2}{|c|}{ Creatinine $(\mathrm{mg} / \mathrm{l})$} \\
\hline & Mean & SE & Mean & SE & Mean & SE & Mean & SE & Mean & SE \\
\hline $\mathrm{R}$ & 3.74 & 0.26 & $40 \cdot 4$ & 0.8 & $710 \cdot 0$ & $36 \cdot 7$ & $108 \cdot 4$ & $5 \cdot 1$ & $8 \cdot 8$ & 0.6 \\
\hline HY-AL & $5 \cdot 88^{*}$ & 0.63 & $37 \cdot 4^{\star}$ & 0.9 & 708.8 & $25 \cdot 9$ & $289.5^{\star}$ & $20 \cdot 7$ & $14 \cdot 8$ & $3 \cdot 0$ \\
\hline $\mathrm{HY}+\mathrm{AL}$ & $6 \cdot 12^{\star}$ & 0.34 & $37 \cdot 4^{\star}$ & 0.8 & 684.4 & $20 \cdot 2$ & $253.8^{*}$ & $16 \cdot 8$ & $18 \cdot 4^{\star}$ & $2 \cdot 2$ \\
\hline $\mathrm{HY}+\mathrm{CP}$ & $6 \cdot 41^{*}$ & 0.22 & $35 \cdot 3^{\star c}$ & 0.7 & $748 \cdot 9^{a, b}$ & $36 \cdot 3$ & $447 \cdot 9^{*} t^{\mathrm{a}}$ & 33.6 & $23 \cdot 9^{*} \dagger$ & $2 \cdot 3$ \\
\hline $\mathrm{HY}+\mathrm{CS}$ & $5 \cdot 21^{*}$ & 0.41 & $38.4^{\mathrm{b}}$ & 0.8 & $651 \cdot 3^{\mathrm{c}}$ & $20 \cdot 6$ & $235 \cdot 2^{* \mathrm{~b}}$ & $22 \cdot 6$ & $21 \cdot 6^{\star}$ & 1.5 \\
\hline $\mathrm{HY}+\mathrm{SP}$ & $5 \cdot 55^{\star}$ & 0.36 & $40 \cdot 2 \dagger^{a, b}$ & $1 \cdot 0$ & $794 \cdot 0^{\star} t^{a}$ & $32 \cdot 3$ & $391.9^{\star} t^{a}$ & $38 \cdot 0$ & $25 \cdot 5^{\star} \dagger$ & 3.5 \\
\hline $\mathrm{HY}+\mathrm{SS}$ & $5 \cdot 32^{*}$ & 0.40 & $41.4 \dagger^{a}$ & 0.6 & $686 \cdot 7^{\mathrm{b}, \mathrm{c}}$ & $25 \cdot 1$ & $258 \cdot 2^{\star \mathrm{b}}$ & $35 \cdot 2$ & $19 \cdot 1^{*}$ & 1.6 \\
\hline \multicolumn{11}{|c|}{ Main effects for four groups (two-way ANOVA) $\ddagger$} \\
\hline Protein & NS & & $<0.001$ & & NS & & NS & & NS & \\
\hline Oil & NS & & 0.009 & & 0.002 & & $<0.001$ & & NS & \\
\hline Interaction & NS & & NS & & NS & & NS & & NS & \\
\hline
\end{tabular}

BUN, blood urea N; R, normal control rats fed with a modified AIN-93M high-fat diet; HY-AL, hyperuricaemic rats fed with casein and maize oil; HY + AL, hyperuricaemic rats fed with casein and maize oil and administered with allopurinol in drinking water; HY + CP, hyperuricaemic rats fed with casein and palm oil; HY + CS, hyperuricaemic rats fed with casein and safflower-seed oil; HY + SP, hyperuricaemic rats fed with soya protein and palm oil; HY + SS, hyperuricaemic rats fed with soya protein and safflower-seed oil; AIN, American Institute of Nutrition.

a,b,c Mean values within a column (among the $\mathrm{HY}+\mathrm{CP}, \mathrm{HY}+\mathrm{CS}, \mathrm{HY}+\mathrm{SP}$ and $\mathrm{HY}+\mathrm{SS}$ groups) with unlike superscript letters were significantly different $(P<0.05)$

* Mean value was significantly different from that of the R group $(P<0.05$; one-way ANOVA and least significant differences).

† Mean value was significantly different from that of the HY-AL group $(P<0.05$; one-way ANOVA and least significant differences).

$\ddagger$ Values of two-way ANOVA are $P$ values for main effects, such as protein, oil and interaction between protein and oil in the $\mathrm{HY}+\mathrm{CP}, \mathrm{HY}+\mathrm{CS}, \mathrm{HY}+\mathrm{SP}$ and $\mathrm{HY}+\mathrm{SS}$ groups. 

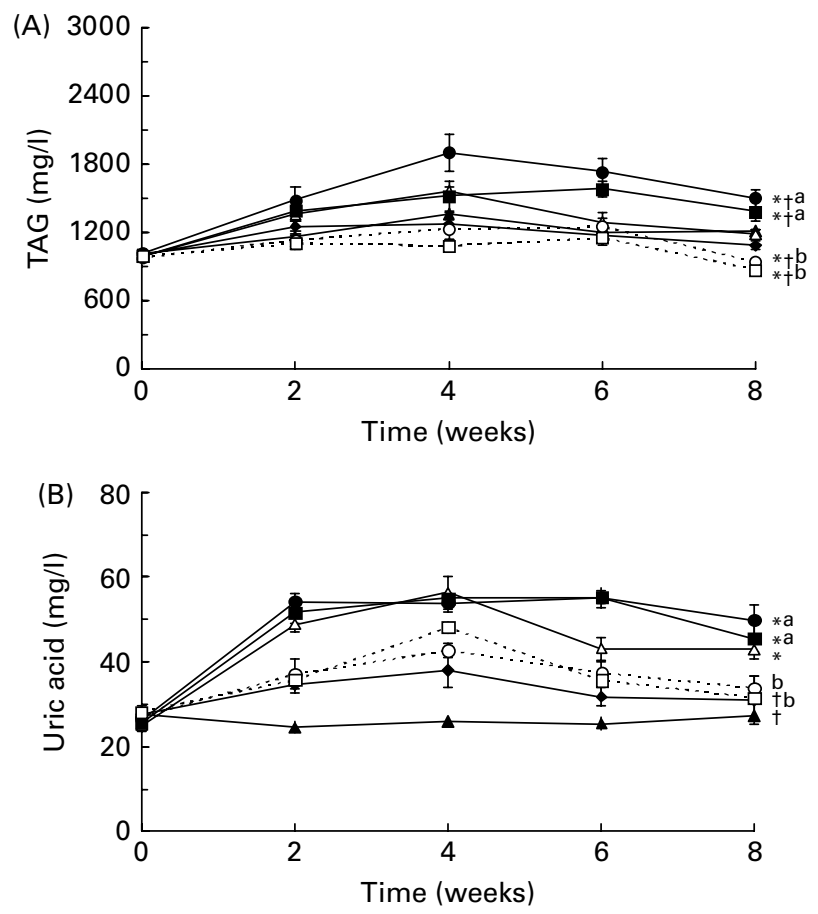

Fig. 2. Serum concentrations of TAG (A) and uric acid (B) during 8 weeks. $(-\boldsymbol{\Lambda}-)$, Normal control rats fed with a modified American Institute of Nutrition (AIN)-93M high-fat diet (R); $(-\Delta-)$, hyperuricaemic rats fed with casein and maize oil (HY-AL); (- -$)$, hyperuricaemic rats fed with casein and maize oil

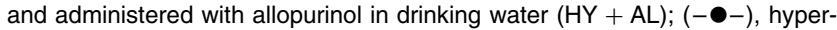
uricaemic rats fed with casein and palm oil $(\mathrm{HY}+\mathrm{CP})$; $(--\mathrm{O}--)$, hyperuricaemic rats fed with casein and safflower-seed oil (HY + CS); (-口-), hyperuricaemic rats fed with soya protein and palm oil (HY + SP); (-- $\square--)$ hyperuricaemic rats fed with soya protein and safflower-seed oil (HY $+\mathrm{SS}$ ). Values are means for nine rats per group, with standard errors represented by vertical bars. ${ }^{*}$ Mean value was significantly different from that of the $R$ group ( $P<0.05$; one-way ANOVA and least significant differences). † Mean value was significantly different from that of the HY-AL group $(P<0.05$; oneway ANOVA and least significant differences). ${ }^{a, b}$ Mean values (among the $\mathrm{HY}+\mathrm{CP}, \mathrm{HY}+\mathrm{CS}, \mathrm{HY}+\mathrm{SP}$ and $\mathrm{HY}+\mathrm{SS}$ groups) with unlike letters were significantly different $(P<0.05)$.

\section{Results}

\section{Whole body growth and food intake}

Body weights are shown in Fig. 1(A). Hyperuricaemic rats, i.e. the HY-AL, HY + AL, HY + CP, HY + CS, HY + SP and $\mathrm{HY}+\mathrm{SS}$ groups, had significantly decreased body weight from week 2 to week 8 compared with normal rats (R group; repeated-measures analysis; $P<0.001)$. The $\mathrm{HY}+\mathrm{SP}$ group showed a further decrease in body weight. Two-way ANOVA indicated that hyperuricaemic rats that had ingested palm oil had significantly decreased body weights compared with those that had ingested safflower-seed oil $(P<0 \cdot 001)$. Body-weight gain in 8 weeks was also significantly lower in hyperuricaemic rats compared with normal rats (Table 2). Hyperuricaemic rats that had ingested palm oil $(\mathrm{HY}+\mathrm{CP}$ and $\mathrm{HY}+\mathrm{SP})$ had significantly $(P<0.001)$ decreased body-weight gain compared with those that had ingested safflower-seed oil $(\mathrm{HY}+\mathrm{CS}$ and $\mathrm{HY}+\mathrm{SS})$.

From week 2 to week 8 , all of the rats were pair-fed with the HY-AL group; however, several rats in the HY + AL, $\mathrm{HY}+\mathrm{CP}$ and $\mathrm{HY}+\mathrm{SP}$ groups did not finish the provided amounts of diets. When calculating the amount of food intake, we did not find a significant difference in weekly food intake among groups (Fig. 1(B)), except for the $\mathrm{HY}+\mathrm{AL}$ group which had significantly decreased food intake on week 2 to week 4 (one-way ANOVA; $P<0 \cdot 001$ ). When calculated as grams of body weight gain per $\mathrm{kJ}$ of food intake in 8 weeks, feed efficiency was significantly lower in hyperuricaemic rats compared with normal rats (Table 2). The HY + CS group had significantly increased and the HY + SP group had significantly decreased feed efficiency compared with the HY-AL group (one-way ANOVA); and casein was the main factor to increase, and palm oil the main factor to decrease, feed efficiency (two-way ANOVA; $P<0.001$ ).

\section{Relative weights of organs and tissues}

The relative weights ( $\mathrm{g} / \mathrm{kg}$ body weight) of the lungs and kidneys (Table 2) were significantly increased in hyperuricaemic rats. Palm oil was the main factor to increase the relative weights of the hearts and lungs $(P<0 \cdot 01)$, and soya protein was the main factor to decrease liver weight and to increase gastrocnemius muscle weight in hyperuricaemic rats.

\section{Circulating leucocytes and serum biochemistry}

The results presented in Table 3 show that hyperuricaemic rats had significantly decreased albumin and increased leucocytes and BUN compared with normal rats. Soya protein significantly increased while palm oil decreased serum albumin in hyperuricaemic rats. In addition, palm oil increased serum cholesterol and BUN. Serum concentrations of TAG and UA are shown in Fig. 2. On weeks 6 and 8, the HY $+\mathrm{CP}$ and $\mathrm{HY}+\mathrm{SP}$ groups had significantly increased and the $\mathrm{HY}+\mathrm{CS}$ and HY + SS groups had significantly decreased serum TAG compared with the R and HY-AL groups (oneway ANOVA and least-significant difference; $P<0 \cdot 05)$. Serum UA concentration was significantly increased in the HY-AL group compared with the $\mathrm{R}$ group from week 2 to week 8 . The HY + AL and HY + SS groups had significantly lower serum UA than the HY-AL group. The results of twoway ANOVA indicated that safflower-seed oil was the main factor to decrease serum TAG and UA $(P<0 \cdot 001)$.

\section{Plasma and renal nitric oxide and cytokines}

Plasma concentrations of insulin, NO and cytokines are shown in Table 4. Plasma insulin concentration was significantly lower in the hyperuricaemic rats than in the normal rats and was significantly greater in the $\mathrm{HY}+\mathrm{CP}$ group than in the $\mathrm{HY}+\mathrm{SP}$ and $\mathrm{HY}+\mathrm{SS}$ groups. Plasma NO was not significantly different among groups; however, plasma TNF- $\alpha$ and IFN- $\gamma$ were significantly greater in the $\mathrm{HY}+\mathrm{CP}$ group than in the $\mathrm{HY}+\mathrm{SP}$ and $\mathrm{HY}+\mathrm{SS}$ groups. Two-way ANOVA indicated that casein was the main factor to increase plasma insulin and IFN- $\gamma$.

In addition, renal NO, nitrotyrosine, TNF- $\alpha$ and IFN- $\gamma$ were significantly decreased, whereas renal TGF- $\beta$ was significantly increased in hyperuricaemic rats compared with normal rats (Table 5). Soya protein was the main factor to decrease renal NO content; soya protein and palm oil were 
Table 4. Plasma insulin, nitric oxide and cytokines in normal and hyperuricaemic rats (Mean values with their standard errors for nine rats per group)

\begin{tabular}{|c|c|c|c|c|c|c|c|c|}
\hline \multirow[b]{2}{*}{ Group } & \multicolumn{2}{|c|}{ Insulin $(\mu \mathrm{g} / \mathrm{l})$} & \multicolumn{2}{|c|}{$\mathrm{NO}(\mu \mathrm{mol} / \mathrm{l})$} & \multicolumn{2}{|c|}{ TNF- $\alpha(\mu \mathrm{g} / \mathrm{l})$} & \multicolumn{2}{|c|}{ IFN- $\gamma(\mu \mathrm{g} / \mathrm{l})$} \\
\hline & Mean & SE & Mean & SE & Mean & SE & Mean & SE \\
\hline $\mathrm{R}$ & 0.705 & 0.069 & 55.8 & 8.4 & 867.4 & 11.9 & $16 \cdot 00$ & 1.83 \\
\hline HY-AL & $0.457^{*}$ & 0.067 & $56 \cdot 8$ & $8 \cdot 1$ & $831 \cdot 1$ & $22 \cdot 9$ & 11.43 & $2 \cdot 15$ \\
\hline $\mathrm{HY}+\mathrm{AL}$ & $0.483^{\star}$ & $0 \cdot 101$ & $82 \cdot 7$ & $12 \cdot 6$ & $836 \cdot 8$ & $34 \cdot 8$ & 11.90 & $2 \cdot 69$ \\
\hline $\mathrm{HY}+\mathrm{CP}$ & $0.887 \dagger^{a}$ & 0.225 & $86 \cdot 6$ & $10 \cdot 1$ & $893 \cdot 6^{\mathrm{a}}$ & $57 \cdot 4$ & $33 \cdot 19^{\star} t^{\mathrm{a}}$ & 3.96 \\
\hline $\mathrm{HY}+\mathrm{CS}$ & $0.604^{\mathrm{a}, \mathrm{b}}$ & 0.088 & 63.9 & 9.7 & $766 \cdot 8^{\star \mathrm{b}}$ & $22 \cdot 2$ & $24 \cdot 42^{*} \dagger^{a, b}$ & $2 \cdot 76$ \\
\hline $\mathrm{HY}+\mathrm{SP}$ & $0.456^{\star b}$ & 0.050 & $88 \cdot 1$ & $6 \cdot 1$ & $760 \cdot 5^{\star b}$ & $25 \cdot 9$ & $22 \cdot 00 t^{b}$ & 3.06 \\
\hline $\mathrm{HY}+\mathrm{SS}$ & $0.377^{\star b}$ & 0.040 & 78.9 & 7.9 & $769 \cdot 0^{\star \mathrm{b}}$ & 23.8 & $20 \cdot 14^{b}$ & 3.55 \\
\hline \multicolumn{9}{|c|}{ Main effects for four groups (two-way ANOVA) $\ddagger$} \\
\hline Protein & 0.007 & & NS & & NS & & 0.020 & \\
\hline Oil & NS & & NS & & NS & & NS & \\
\hline Interaction & NS & & NS & & NS & & NS & \\
\hline
\end{tabular}

IFN, interferon; $R$, normal control rats fed with a modified AIN-93M high-fat diet; HY-AL, hyperuricaemic rats fed with casein and maize oil; $H Y+A L$, hyperuricaemic rats fed with casein and maize oil and administered with allopurinol in drinking water; HY + CP, hyperuricaemic rats fed with casein and palm oil; HY + CS, hyperuricaemic rats fed with casein and safflower-seed oil; HY + SP, hyperuricaemic rats fed with soya protein and palm oil; HY + SS, hyperuricaemic rats fed with soya protein and safflower-seed oil; AIN, American Institute of Nutrition.

${ }^{a, b}$ Mean values within a column (among the HY $+\mathrm{CP}, \mathrm{HY}+\mathrm{CS}, \mathrm{HY}+\mathrm{SP}$ and $\mathrm{HY}+\mathrm{SS}$ groups) with unlike superscript letters were significantly different $(P<0.05)$.

* Mean value was significantly different from that of the $\mathrm{R}$ group $(P<0.05$; one-way ANOVA and least significant differences)

$\dagger$ Mean value was significantly different from that of the HY-AL group $(P<0.05$; one-way ANOVA and least significant differences).

$\ddagger$ Values of two-way ANOVA are $P$ values for main effects, such as protein, oil and interaction between protein and oil in the HY $+\mathrm{CP}$, $\mathrm{HY}+\mathrm{CS}$, $\mathrm{HY}+\mathrm{SP}$ and $\mathrm{HY}+\mathrm{SS}$ groups.

the main factors to decrease renal nitrotyrosine; and palm oil was the main factor to decrease renal TNF- $\alpha$ and IFN- $\gamma$ and to increase renal TGF- $\beta$.

\section{Morphological assessments of kidney sections}

The results of histological assessments of kidney sections in PAS stains and the grades of renal damage are shown in Fig. 3 and Table 6, respectively. In comparison with normal rats (Fig. 3(A)), hyperuricaemic rats (Fig. 3(B)) exhibited extended tubular injury, including severe tubulointerstitial nephritis, lymphoplasmacytosis, fibrosis and intralesional severe renal tubular regeneration and dilation, associated with filled PAS positive material, calcification and feathery urate crystals. In addition, the grades of renal damage, including tubulointerstitial nephritis, intralesional calcification, urate crystallisation and fibrosis were significantly greater in hyperuricaemic rats than in normal rats (Table 6; $P<0.001)$. The grades of renal damage were not significantly different among the hyperuricaemic groups, except for the HY + CS group, which had significantly attenuated tubular injury, PAS positive material (Fig. 3(E)) and renal damage (Table 6) compared with the other hyperuricaemic groups.

Table 5. Renal nitric oxide and cytokines in normal and hyperuricaemic rats (Mean values with their standard errors for nine rats per group)

\begin{tabular}{|c|c|c|c|c|c|c|c|c|c|c|}
\hline \multirow[b]{2}{*}{ Group } & \multicolumn{2}{|c|}{$\mathrm{NO}(\mu \mathrm{mol} / \mathrm{l})$} & \multicolumn{2}{|c|}{$\begin{array}{l}\text { Nitrotyrosine } \\
(\mu \mathrm{mol} / \mathrm{l})\end{array}$} & \multicolumn{2}{|c|}{ TNF- $\alpha(\mu \mathrm{g} / \mathrm{l})$} & \multicolumn{2}{|c|}{$\mathrm{IFN}-\gamma(\mu \mathrm{g} / \mathrm{l})$} & \multicolumn{2}{|c|}{ TGF- $\beta(\mu \mathrm{g} / \mathrm{l})$} \\
\hline & Mean & SE & Mean & $\mathrm{SE}$ & Mean & $\mathrm{SE}$ & Mean & SE & Mean & SE \\
\hline $\mathrm{R}$ & $549 \cdot 1$ & $45 \cdot 7$ & $9 \cdot 71$ & 0.59 & $17 \cdot 30$ & 0.47 & $16 \cdot 28$ & 0.21 & $1 \cdot 25$ & 0.12 \\
\hline HY-AL & $442 \cdot 7^{\star}$ & 44.4 & $7 \cdot 02^{*}$ & 0.46 & $11 \cdot 75^{\star}$ & 0.69 & $12 \cdot 73^{*}$ & 0.62 & $2 \cdot 79^{\star}$ & 0.25 \\
\hline$H Y+A L$ & $396 \cdot 3^{*}$ & $30 \cdot 9$ & $4 \cdot 94^{*} \dagger$ & 0.55 & $12 \cdot 26^{*}$ & 0.99 & $13.78^{*}$ & 0.80 & $2 \cdot 08^{\star}$ & 0.14 \\
\hline $\mathrm{HY}+\mathrm{CP}$ & $331 \cdot 3^{\star} t^{a, b}$ & $23 \cdot 3$ & $3 \cdot 39^{*} t^{b}$ & 0.54 & $9 \cdot 41^{\star b, c}$ & 0.93 & $11 \cdot 09^{\star b, c}$ & 0.90 & $3 \cdot 34^{\star a}$ & 0.17 \\
\hline $\mathrm{HY}+\mathrm{CS}$ & $395 \cdot 5^{\star 2}$ & $25 \cdot 3$ & $5 \cdot 86^{\star a}$ & 0.71 & $13 \cdot 42^{\star a}$ & 1.05 & $14 \cdot 72^{\mathrm{a}}$ & 0.81 & $2 \cdot 22^{* b}$ & 0.37 \\
\hline $\mathrm{HY}+\mathrm{SP}$ & $232 \cdot 8^{*} t^{c}$ & $34 \cdot 3$ & $2 \cdot 73^{*} t^{b}$ & 0.30 & $8 \cdot 39^{*} \dagger^{c}$ & 0.47 & $10 \cdot 27^{\star} t^{c}$ & 0.62 & $3.58^{\star a}$ & 0.24 \\
\hline $\mathrm{HY}+\mathrm{SS}$ & $252 \cdot 7^{*} t^{b, c}$ & $30 \cdot 8$ & $3 \cdot 90^{*} t^{b}$ & 0.58 & $11 \cdot 60^{\star a, b}$ & 0.85 & $13 \cdot 13^{\star a, b}$ & 0.77 & $2 \cdot 82^{\star a, b}$ & 0.47 \\
\hline \multicolumn{11}{|c|}{ Main effects for four groups (two-way ANOVA) $\ddagger$} \\
\hline Protein & $<0.001$ & & 0.021 & & NS & & NS & & NS & \\
\hline Oil & NS & & 0.002 & & $<0.001$ & & $<0.001$ & & 0.008 & \\
\hline Interaction & NS & & NS & & NS & & NS & & NS & \\
\hline
\end{tabular}

IFN, interferon; TGF, transforming growth factor; $\mathrm{R}$, normal control rats fed with a modified AIN-93M high-fat diet; HY-AL, hyperuricaemic rats fed with casein and maize oil; $\mathrm{HY}+\mathrm{AL}$, hyperuricaemic rats fed with casein and maize oil and administered with allopurinol in drinking water; $\mathrm{HY}+\mathrm{CP}$, hyperuricaemic rats fed with casein and palm oil; $\mathrm{HY}+\mathrm{CS}$, hyperuricaemic rats fed with casein and safflower-seed oil; HY + SP, hyperuricaemic rats fed with soya protein and palm oil; HY + SS, hyperuricaemic rats fed with soya protein and safflower-seed oil; AIN, American Institute of Nutrition.

${ }^{\mathrm{a}, \mathrm{b}, \mathrm{c}}$ Mean values within a column (among the $\mathrm{HY}+\mathrm{CP}, \mathrm{HY}+\mathrm{CS}, \mathrm{HY}+\mathrm{SP}$ and $\mathrm{HY}+\mathrm{SS}$ groups) with unlike superscript letters were significantly different $(P<0.05)$.

* Mean value was significantly different from that of the R group $(P<0.05$; one-way ANOVA and least significant differences).

† Mean value was significantly different from that of the HY-AL group $(P<0.05$; one-way ANOVA and least significant differences).

$\ddagger$ Values of two-way ANOVA are $P$ values for main effects, such as protein, oil and interaction between protein and oil in the $\mathrm{HY}+\mathrm{CP}$, $\mathrm{HY}+\mathrm{CS}$, $\mathrm{HY}+\mathrm{SP}$ and $\mathrm{HY}+\mathrm{SS}$ groups. 
(A)

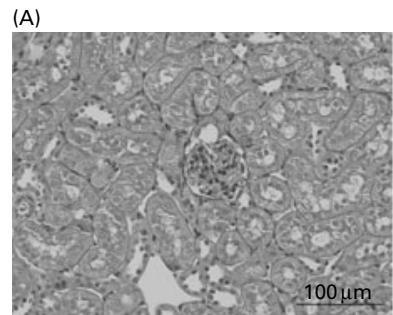

(C)

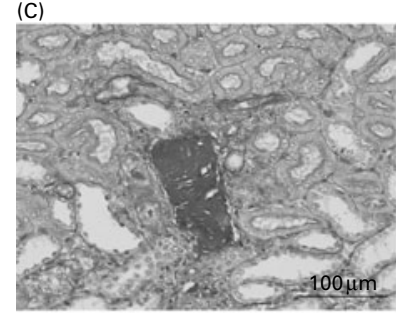

(E)

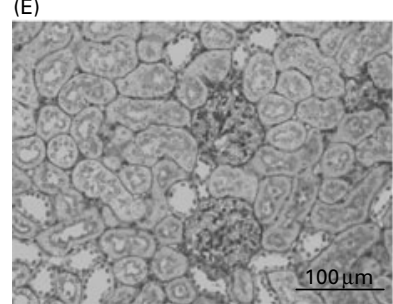

(G)

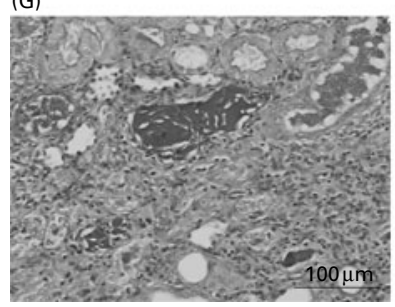

(B)

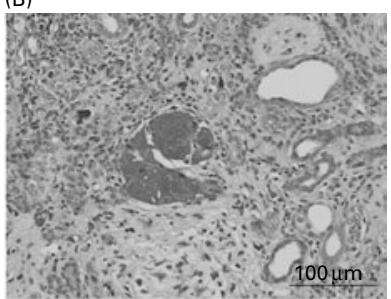

(D)

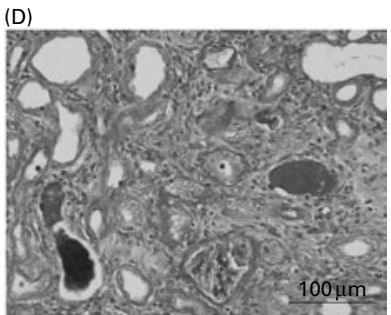

(F)

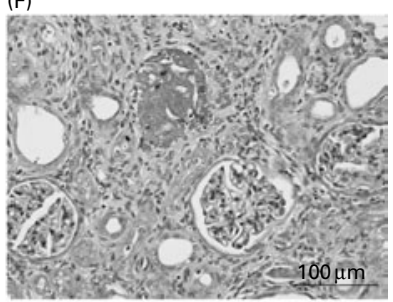

Fig. 3. Light micrographs of kidney sections stained with periodic acid-Schiff (PAS; magnification $200 \times$; bars $=100 \mu \mathrm{m}$ ) of: $(A)$ normal control rats fed with a modified American Institute of Nutrition (AIN)-93M high-fat diet (R); (B) hyperuricaemic rats fed with casein and maize oil (HY-AL); (C) hyperuricaemic rats fed with casein and maize oil and administered with allopurinol in drinking water $(H Y+A L)$; $(D)$ hyperuricaemic rats fed with casein and palm oil $(\mathrm{HY}+\mathrm{CP})$; $(\mathrm{E})$ hyperuricaemic rats fed with casein and safflower-seed oil (HY + CS); ( $F)$ hyperuricaemic rats fed with soya protein and palm oil $(H Y+S P) ;(G)$ hyperuricaemic rats fed with soya protein and safflowerseed oil (HY + SS). Except for the HY + CS group (E), hyperuricaemic rats ( $B$ to $D, F$ and $G$ ) exhibited extended tubular injury with $P A S$ positive material, calcification and feathery urate crystals compared with the normal rats $(A)$.

\section{Discussion}

Epidemiological evidence suggests that a decrease in serum UA may attenuate renal disease progression ${ }^{(8)}$. Using rats administered with OA, a uricase inhibitor, and UA, we confirmed that hyperuricaemia results in renal damage, whereas allopurinol treatment did not attenuate this damage. So far, there is no dietary consensus for individuals with hyperuricaemia, especially for those with renal damage. A soya-based diet supplemented with UFA is hypothesised to be beneficial in decreasing serum UA and attenuating the complications of hyperuricaemia. Therefore, we investigated the effects of casein $v$. soya protein with two commonly used plant oils with different fatty acid components, i.e. palm (palmitic and oleic acid-rich) and safflower-seed (linoleic acid-rich) oils, on several serological parameters and renal damage in hyperuricaemic rats. The rationale for choosing these two oils is because of their notably diverse fatty acid components; for example, the UFA:SFA ratio of palm oil is close to $1^{(22)}$ and that of safflower-seed oil is close to $10^{(23)}$.

In the present study, after being administered with OA and UA for 8 weeks, the rats had significantly increased serum UA and BUN and decreased body-weight gain, feed efficiency and serum albumin. These results suggest that hyperuricaemia may interfere with anabolism. Human and animal studies have demonstrated that hyperuricaemia may result in the deposition of urate crystals in the tubular system, leading to renal failure $^{(6,14,24)}$. Prolonged hyperuricaemia may worsen the progression of renal disease by inactivating NO synthase and augmenting inflammatory responses ${ }^{(4,5,8,10)}$. In the present study we found that hyperuricaemic rats had significantly elevated circulating leucocytes, kidney weights and renal TGF- $\beta$ (a pivotal protein in the pathogenesis of renal fibrosis), and recognisable morphological changes in the kidneys, such as extended tubular injury and elevated PAS positive material (Fig. 3 and Table 6). In addition, the renal contents of $\mathrm{NO}$ and nitrotyrosine, an indicator of NO production, were significantly decreased in hyperuricaemic rats. These results suggest that UA inactivates NO synthase ${ }^{(25)}$ and further causes renal damage and cell dysfunction, as shown in the decreased productions of TNF- $\alpha$ and IFN- $\gamma$ in the kidneys. Taken together, the present results clearly indicate that hyperuricaemia may result in decreased anabolism and extended renal damage.

Allopurinol, an inhibitor of xanthine oxidase that mainly works to decrease UA production, is recommended as a first-line UA-lowering therapy in patients with hyperuricaemia $^{(8)}$. Recent clinical studies have shown that allopurinol has serious toxicity in a small number of patients with renal impairment ${ }^{(26,27)}$. In the present study, the allopurinol-treated hyperuricaemic rats had significantly decreased amounts of food intake on weeks 2 to 4 . This decrease might be related to the bitter taste of allopurinol in drinking water. However, the food intake was increased and the catch-up growth occurred on week 5 . We also found that allopurinol administration did not improve renal damage in rats treated with OA and UA, even though serum UA was significantly decreased. These results imply that allopurinol may effectively maintain serum UA concentrations via decreasing UA production and/ or increasing UA excretion; however, the formation of urate crystals may occur in the renal tubules and interstitial tissue to induce renal damage (Fig. 3(C) and Table 6).

Accumulating evidences has demonstrated that soya-based diets may improve hyperlipidaemia ${ }^{(28-30)}$, renal function ${ }^{(31,32)}$ and progression in chronic renal disease ${ }^{(18,33)}$, which may be related to soya protein-induced increases in NO generation and decreases in oxidative stress and TGF- $\beta$ expression ${ }^{(34)}$. Recently, soya-based diets with UFA have been promoted as a way to alleviate hyperuricaemia and to halt the progression of renal disease. In the present study, we found that both casein and soya protein combined with safflower-seed oil significantly decreased serum TAG in hyperuricaemic rats. In addition, casein plus safflower-seed oil significantly increased body-weight gain, feed efficiency and renal contents of NO, nitrotyrosine, TNF- $\alpha$ and IFN- $\gamma$, as well as significantly decreasing serum cholesterol, BUN, and UA and renal TGF- $\beta$ content. The morphological results further 
Table 6. Grade of renal damage in normal and hyperuricaemic ratsł

(Mean values with their standard errors for nine rats per group)

\begin{tabular}{|c|c|c|c|c|c|c|c|c|}
\hline \multirow[b]{2}{*}{ Group } & \multicolumn{2}{|c|}{$\begin{array}{l}\text { Tubulointerstitial } \\
\text { nephritis }\end{array}$} & \multicolumn{2}{|c|}{$\begin{array}{l}\text { Intralesional } \\
\text { calcification }\end{array}$} & \multicolumn{2}{|c|}{ Urate crystal } & \multicolumn{2}{|c|}{ Fibrosis } \\
\hline & Mean & $\mathrm{SE}$ & Mean & SE & Mean & $\mathrm{SE}$ & Mean & $\mathrm{SE}$ \\
\hline $\mathrm{R}$ & 0.0 & 0.0 & 0.11 & 0.11 & 0.0 & 0.0 & 0.0 & 0.0 \\
\hline HY-AL & $4 \cdot 0^{\star}$ & 0.0 & $1.50^{*}$ & 0.27 & $2 \cdot 0^{\star}$ & 0.0 & $4 \cdot 0^{*}$ & 0.0 \\
\hline $\mathrm{HY}+\mathrm{AL}$ & $4 \cdot 0^{*}$ & 0.0 & $1.78^{\star}$ & 0.22 & $2 \cdot 0^{\star}$ & 0.0 & $4 \cdot 0^{*}$ & 0.0 \\
\hline $\mathrm{HY}+\mathrm{CP}$ & $4 \cdot 0^{\star a}$ & 0.0 & $2 \cdot 00^{\star}$ & 0.01 & $2 \cdot 0^{* a}$ & 0.0 & $4 \cdot 0^{\star a}$ & 0.0 \\
\hline $\mathrm{HY}+\mathrm{CS}$ & $3 \cdot 0^{\star} t^{b}$ & 0.0 & $1.56^{\star}$ & 0.29 & $1 \cdot 0^{*} t^{b}$ & 0.0 & $1 \cdot 0^{*} t^{b}$ & 0.0 \\
\hline $\mathrm{HY}+\mathrm{SP}$ & $4 \cdot 0^{* a}$ & 0.0 & $2 \cdot 00^{\star}$ & 0.01 & $2 \cdot 0^{\star a}$ & 0.0 & $4 \cdot 0^{\star a}$ & 0.0 \\
\hline $\mathrm{HY}+\mathrm{SS}$ & $4 \cdot 0^{* a}$ & 0.0 & $1.56^{*}$ & 0.29 & $2 \cdot 0^{\star a}$ & 0.0 & $4 \cdot 0^{\star a}$ & 0.0 \\
\hline
\end{tabular}

$\mathrm{R}$, normal control rats fed with a modified AIN-93M high-fat diet; HY-AL, hyperuricaemic rats fed with casein and maize oil; HY $+\mathrm{AL}$, hyperuricaemic rats fed with casein and maize oil and administered with allopurinol in drinking water; $\mathrm{HY}+\mathrm{CP}$, hyperuricaemic rats fed with casein and palm oil; $\mathrm{HY}+\mathrm{CS}$, hyperuricaemic rats fed with casein and safflower-seed oil; HY + SP, hyperuricaemic rats fed with soya protein and palm oil; HY + SS, hyperuricaemic rats fed with soya protein and safflower-seed oil; AIN, American Institute of Nutrition.

a,b Mean values within a column (among the HY $+\mathrm{CP}, \mathrm{HY}+\mathrm{CS}, \mathrm{HY}+\mathrm{SP}$ and $\mathrm{HY}+\mathrm{SS}$ groups) with unlike superscript letters were significantly different $(P<0.05)$.

* Mean value was significantly different from that of the $\mathrm{R}$ group $(P<0.05$; Kruskal-Wallis test).

† Mean value was significantly different from that of the HY-AL group $(P<0.05$; Kruskal-Wallis test).

$\ddagger$ The extent of injury was graded as 0 for absent; 1 for trace ( 1 to $25 \%$ of the area); 2 for weak ( 25 to $50 \%$ of the area); 3 for moderate ( 50 to $75 \%$ of the area); 4 for strong ( 75 to $100 \%$ of the area).

demonstrated the beneficial effects of casein plus safflowerseed oil in improving hyperuricaemia-induced renal damage, as shown in the attenuated tubular injury, dilation, and PAS positive material (Fig. 3). Moreover, soya protein plus safflower-seed oil significantly decreased serum TAG and UA (Fig. 2). These anti-hyperlipidaemic and anti-hyperuricaemic activities were closely associated with the consumption of safflower-seed oil (two-way ANOVA; $P<0.001$ ). In the present study, we excluded the possibility that energy restriction is the main factor to result in the serological changes and renal damage in hyperuricaemic rats. One of the reasons is that the palm oil-fed rats tended to have lower food intake but had significantly increased serum TAG and UA compared with the safflower-seed oil-fed rats. In addition, animals with casein combined with safflower-seed oil had significantly attenuated hyperuricaemia-induced renal injury and their food intake and body weight were similar to those with soya protein combined with safflower-seed oil. The mechanisms of casein plus safflower-seed oil in improving renal damage and soya protein plus safflower-seed oil in decreasing serum TAG in hyperuricaemia need to be further investigated.

Reports in the literature suggest that palm oil may attenuate arterial thrombosis, atherosclerosis ${ }^{(35)}$ and hypertension via elevations in endothelial $\mathrm{NO}$ and a reduction in oxidative stress $^{(22)}$. However, we found inconsistent results in OA- and UA-induced hyperuricaemic rats. For example, the bodyweight gain, food intake and renal nitrotyrosine, TNF- $\alpha$ and IFN- $\gamma$ contents were significantly decreased, whereas heart weight, serum TAG (Fig. 2(A)), cholesterol, BUN, creatinine (Table 3 ) and renal TGF- $\beta$ content (Table 5) were significantly increased in rats with palm oil. These adverse effects are possibly because the palm oil was melted by heat for $5 \mathrm{~min}$ when we prepared the semi-purified powdered diet. This oxidised palm oil may have worsened lipid profiles and have been toxic to organs, as shown in previous studies ${ }^{(19,36,37)}$.

It has been indicated that fatty acid compositions of the kidneys are associated with renal function and morphological changes in Han:SPRD-cy heterozygous rats ${ }^{(38)}$. In addition, these changes may be influenced by the dietary contents. For example, diets rich in conjugated linoleic acid significantly reduce fibrosis, macrophage infiltration, tissue oxidised LDL content and proliferation of epithelial cells in the kidneys ${ }^{(39)}$. The pitfall of the present study is that fatty acid compositions of the plasma and kidneys were not determined to explain the possible mechanism of soya protein plus safflower-seed oil in attenuating hyperuricaemia and casein plus safflower-seed oil in improving hyperuricaemiainduced renal damage. The effects of dietary contents on circulating and tissue fatty acid composition and tissue function require further investigation.

In summary, the present study indicates that OA- and UA-induced hyperuricaemia may decrease anabolism and result in renal damage, as shown in the significantly elevated leucocytes, BUN and renal TGF- $\beta$, decreased renal $\mathrm{NO}$, and extended tubular injury and urate crystals. Allopurinol may decrease serum UA; however, the hyperuricaemiainduced renal damage was not improved. In hyperuricaemic rats, safflower-seed oil had an anti-hyperlipidaemic effect, whereas palm oil had a hyperlipidaemic effect and may have augmented renal dysfunction, as evidenced by increased TAG, BUN, creatinine and renal TGF- $\beta$. Moreover, soya protein combined with safflower-seed oil significantly attenuated hyperuricaemia and casein combined with safflower-seed oil significantly attenuated hyperuricaemia-induced renal injury. The utilisation of casein or soya protein plus safflower-seed oil in improving hyperuricaemia-associated complications in human subjects needs to be investigated further.

\section{Acknowledgements}

The present study is supported by Changhua Christian Hospital (grant no. 96-CCH-IPI-09).

H.-C. L. and Y. Y. designed the study. H.-C. L. conducted the animal study and wrote the manuscript. Y.-H. W. and S.-H. L. contributed to sample analyses and statistical analyses. H.-Y. C. conducted the tissue section analysis and picture preparation. Y. Y. critically reviewed the manuscript. H.-C. L. was the principal investigator who supervised aspects of the whole study.

The authors declare that there are no conflicts of interest. 


\section{References}

1. Chang HY, Pan WH, Yeh WT, et al. (2001) Hyperuricemia and gout in Taiwan: results from the Nutritional and Health Survey in Taiwan (1993-96). J Rheumatol 28, 1640-1646.

2. Lee MS, Lin SC, Chang HY, et al. (2005) High prevalence of hyperuricemia in elderly Taiwanese. Asia Pac J Clin Nutr 14, 285-292.

3. Huang CC, Peng MC, Tsai WC, et al. (2005) The serum uric acid and related cardiovascular risk factors in south Taiwan. Southeast Asian J Trop Med Public Health 36, 259-264.

4. Menè P \& Punzo G (2008) Uric acid: bystander or culprit in hypertension and progressive renal disease? J Hypertens $\mathbf{2 5}$, 2085-2092.

5. Mazzali M, Hughes J, Kim YG, et al. (2001) Elevated uric acid increases blood pressure in the rat by a novel crystalindependent mechanism. Hypertension 38, 1101-1106.

6. Johnson RJ, Titte S, Cade JR, et al. (2005) Uric acid, evolution and primitive cultures. Semin Nephrol 25, 3-8.

7. Erdogan D, Gullu H, Caliskan M, et al. (2005) Relationship of serum uric acid to measures of endothelial function and atherosclerosis in healthy adults. Int $J$ Clin Pract 59, 1276-1282.

8. Kang DH \& Nakagawa T (2005) Uric acid and chronic renal disease: possible implication of hyperuricemia on progression of renal disease. Semin Nephrol 25, 43-49.

9. Bellinghieri G, Santoro D \& Savica V (2005) Pharmacological treatment of acute and chronic hyperuricemia in kidney diseased patients. Contrib Nephrol 147, 149-160.

10. Ejaz AA, Mu W, Kang DH, et al. (2007) Could uric acid have a role in acute renal failure? Clin J Am Soc Nephrol 2, $16-21$.

11. Nakagawa T, Mazzali M, Kang DH, et al. (2003) Hyperuricemia causes glomerular hypertrophy in the rat. Am J Nephrol 23, 2-7.

12. Sánchez-Lozada LG, Tapia E, Santamaría J, et al. (2005) Mild hyperuricemia induces vasoconstriction and maintains glomerular hypertension in normal and remnant kidney rats. Kidney Int 67, 237-247.

13. Iseki K, Ikemiya $\mathrm{Y}$, Inoue $\mathrm{T}$, et al. (2004) Significance of hyperuricemia as a risk factor for developing ESRD in a screened cohort. Am J Kidney Dis 44, 642-650.

14. Kutzing MK \& Firestein BL (2008) Altered uric acid levels and disease states. J Pharmacol Exp Ther 324, 1-7.

15. Peixoto MR, Monego ET, Jardim PC, et al. (2001) Diet and medication in the treatment of hyperuricemia in hypertensive patients. Arq Bras Cardiol 76, 463-472.

16. Johnson RJ \& Rideout BA (2004) Uric acid and diet - insights into the epidemic of cardiovascular disease. N Engl J Med 350, 1071-1073.

17. Fam AG (2002) Gout, diet, and the insulin resistance syndrome. $J$ Rheumatol 29, 1350-1355.

18. Fair DE, Ogborn MR, Weiler HA, et al. (2004) Dietary soy protein attenuates renal disease progression after 1 and 3 weeks in Han:SPRD-cy weanling rats. J Nutr 134, 1504-1507.

19. Aguila MB, Pinheiro AR, Aquino JC, et al. (2005) Different edible oil beneficial effects (canola oil, fish oil, palm oil, olive oil, and soybean oil) on spontaneously hypertensive rat glomerular enlargement and glomeruli number. Prostaglandins Other Lipid Mediat 76, 74-85.

20. Bernstein AM, Treyzon L \& Li Z (2007) Are high-protein, vegetable-based diets safe for kidney function? A review of the literature. J Am Diet Assoc 107, 644-650.
21. Shih W, Hines WH \& Neilson EG (1988) Effects of cyclosporine $\mathrm{A}$ on the development of immune-mediated interstitial nephritis. Kidney Int 33, 1113-1118.

22. Bayorh MA, Abukhalaf IK \& Ganafa AA (2005) Effect of palm oil on blood pressure, endothelial function and oxidative stress. Asia Pac J Clin Nutr 14, 325-339.

23. Cosge B, Gurbuz B \& Kiralan M (2007) Oil content and fatty acid composition of some safflower (Carthamus tinctorius L.) varieties sown in spring and winter. Int J Natural Eng Sci 1, $11-15$.

24. Avram Z \& Krishnan E (2008) Hyperuricaemia - where nephrology meets rheumatology. Rheumatology 47, 960-964.

25. Khosla UM, Zharikov S, Finch JL, et al. (2005) Hyperuricemia induces endothelial dysfunction. Kidney Int 67, 1739-1742.

26. Dalbeth N \& Stamp L (2007) Allopurinol dosing in renal impairment: walking the tightrope between adequate urate lowering and adverse events. Semin Dial 20, 391-395.

27. Markel A (2005) Allopurinol-induced DRESS syndrome. Isr Med Assoc J 7, 656-660.

28. Ogborn MR, Nitschmann E, Weiler HA, et al. (2000) Modification of polycystic kidney disease and fatty acid status by soy protein diet. Kidney Int 57, 159-166.

29. Tovar AR, Murguía F, Cruz C, et al. (2002) A soy protein diet alters hepatic lipid metabolism gene expression and reduces serum lipids and renal fibrogenic cytokines in rats with chronic nephrotic syndrome. J Nutr 132, 2562-2569.

30. Azadbakht L, Atabak S \& Esmaillzadeh A (2008) Soy protein intake, cardiorenal indices, and C-reactive protein in type 2 diabetes with nephropathy: a longitudinal randomized clinical trial. Diabetes Care 31, 648-654.

31. Teixeira SR, Tappenden KA, Carson L, et al. (2004) Isolated soy protein consumption reduces urinary albumin excretion and improves the serum lipid profile in men with type 2 diabetes mellitus and nephropathy. J Nutr 134, 1874-1880.

32. Azadbakht L, Shakerhosseini R, Atabak S, et al. (2003) Beneficiary effect of dietary soy protein on lowering plasma levels of lipid and improving kidney function in type II diabetes with nephropathy. Eur J Clin Nutr 57, 1292-1294.

33. Chen ST, Yang HY, Huang HY, et al. (2006) Effects of various soya protein hydrolysates on lipid profile, blood pressure and renal function in five-sixths nephrectomized rats. $\mathrm{Br} J \mathrm{Nutr}$ 96, 435-441.

34. Trujillo J, Cruz C, Tovar A, et al. (2008) Renoprotective mechanisms of soy protein intake in the obese Zucker rat. Am J Physiol Renal Physiol 295, F1574-F1582.

35. Ganafa AA, Socci RR, Eatman D, et al. (2002) Effect of palm oil on oxidative stress-induced hypertension in SpragueDawley rats. Am J Hypertens 15, 725-731.

36. Edem DO (2002) Palm oil: biochemical, physiological, nutritional, hematological, and toxicological aspects: a review. Plant Foods Hum Nutr 57, 319-341.

37. Leong XF, Aishah A, Nor Aini U, et al. (2008) Heated palm oil causes rise in blood pressure and cardiac changes in heart muscle in experimental rats. Arch Med Res 39, $567-572$.

38. Ogborn MR, Nitschmann E, Bankovic-Calic N, et al. (2002) Dietary flax oil reduces renal injury, oxidized LDL content, and tissue $n-6 / n-3$ FA ratio in experimental polycystic kidney disease. Lipids 37, 1059-1065.

39. Ogborn MR, Nitschmann E, Goldberg A, et al. (2008) Dietary conjugated linoleic acid renal benefits and possible toxicity vary with isomer, dose and gender in rat polycystic kidney disease. Lipids 43, 783-791. 